\title{
Ecological consequences of deforestation and afforestation on a post-arable land: Changes in the composition and structure of plant communities and transformations of oak-hornbeam habitats and soil
}

\author{
Grażyna Laska \\ Department of Environmental Protection and Management, Białystok Technical University, \\ Wiejska 45a, 15-351 Białystok, Poland; e-mail: g.laska@pb.edu.pl
}

\begin{abstract}
The species composition and structure of secondary communities developed after deforestation in fertile oak-hornbeam habitats and afforestation of post-arable land from Tilio-Carpinetum and Melitti-Carpinetum circles in the Knyszyńska Forest have been studied. The analysis was based on 178 relevés made by Braun-Blanquet method, including 47 relevés of oak-hornbeam natural communities, 59 relevés of post-clear-cutting communities after deforestation and 72 releves of five secondary forest communities, 30-59 years old forming the first generation of trees on post-arable land. The types of habitats, types of soil and surface geological formations were identified, while soil samples were subjected to chemical analysis.

The degree of deterioration of secondary communities on post-arable land was found to be the greater the shorter the time from abandonment of agricultural use of a given area. As a result of former cultivation the soil has been degraded and the composition and structure of plant communities have been altered. The identified vegetation patches show changes characteristic of IV and V phase of degeneration and deformations manifested as cespitization, apophytization and bryophytization. The oak-hornbeam habitats represent the weakly (d) or strongly (D) degraded habitats, with the soil upper layer transformed by tilling into a ploughing horizon (Ap), with changes in the form of humus and considerable simplification in morphology of soil profiles.
\end{abstract}

Key words: post-clear-cutting communities, the secondary forest communities, soil profiles, habitat fertility, anthropogenic transformation.

\section{Introduction}

According to the periodization of anthropopressure by Olaczek (1972), the period of intense clearing of deciduous forests to get land for agricultural use that took place from the $13^{\text {th }}$ to $18^{\text {th }}$ century $\mathrm{AD}$, has brought the largest contribution to transformation of fertile oak-hornbeam habitats into meadows, arable land and pastures. The change of land use from forest to the land of agricultural use was closely related to development of settlements, agriculture and animal breeding. Mainly the forests growing in fertile oak-hornbeam habitats, flood-plain habitats and thermo- philous oak forest habitats were clear-cut for agricultural use (Olaczek 1972).

In the 1990s, the economic changes in Poland have forced the abandonment of some arable land and some of it has been reforested (Matuszkiewicz et al. 2013a). The changes in species composition and structure of plant communities, transformations of oak-hornbeam habitats and soil related to intense deforestation followed by reforestation of land used in the meantime for agricultural purposes are a consequence of the fact that irrespective of the production potential of habitats, the species preferred for reforestation were those of low climatic and trophic requirements and characterised by fast growing (Zerbe 
2002; Humphrey et al. 2004; Ito et al. 2004; Hiromi et al. 2006; Stephens \& Wagner 2007). In the mesotrophic and oligrophic habitats in Poland the species best meeting the above requirements is Pinus sylvestris L., which for the last two centuries has been predestined to be a dominant species in Polish forests (Matuszkiewicz et al. 2013b). The monoculture domination of pine for the last two centuries has resulted in simplification and impoverishment of species composition of tree stands leading to the present different forms of secondary communities (Lindgren \& Sullivan 2001; Chinea \& Helmer 2003; Jones et al. 2009). The communities that have developed under the impact of human activity as secondary combinations of species are called the secondary anthropogenic communities (Olaczek 1972; Łaska 2006). They are characterised by disturbed structure and internal balance, diverse floristic composition the herbal layer in which the species prefer facial domination in the form of single species aggregations and patches. They appear as a manifestation of synanthropisation of the vegetation cover as a result of substitution of the primary complex and multifunctional systems with secondary simple and monofunctional ones (Faliński 1972). The secondary communities have been studied by many authors. Some of them have concentrated on the causes of appearance of the latter and analysed the effect of tree felling on changes in the special composition and structure of post-clear-cut communities (Laska 2000; Deal 2001; Deal \& Tappeiner 2002; Gilliam 2002; Haeussler \& Bergeron 2004), while others have been focused on the impact of of tree-felling and different type deformations of forest communities (Olaczek 1974; Holgen \& Hanell 2000; Jalonen \& Vanha-Majamaa 2001; MacDonald \& Thompson 2003; Burke et al. 2008). Many authors have made attempts at identification and classification of secondary forest communities and analysed their variations following from different directions of anthropogenic transformations (Bell \& Newmaster 2002; Łaska 2002, 2006; Allison et al. 2003). The studies also concerned the processes of formation of secondary communities in different type habitats (eutrophic, mesotrophic and oligotrophic). For instance the ecological effects of different types of forest clear-cutting, conditions for renewal of trees, changes in the type of soil, soil transformations, chemistry of the upper genetic levels, changes in habitats, evaluation of habitats trophic state and degree of transformation as a result of forest management procedures (Siira-Pietikäinen et al. 2001, 2003; Hannam et al. 2005). The aim of this study is evaluation of ecological effects of deforestation and reforestation of post-agricultural use land in view of the changes in the composition and structure of plant communities and transformations of oak-hornbeam habitats and soil.

\section{Study area}

The area of study was the Knyszyńska Forest in north-eastern Poland. The area of the Knyszynska Forest comprises a forest complex covering $1267.02 \mathrm{~km}^{2}$ (126702 ha), of which $744.47 \mathrm{~km}^{2}$ belongs to the Landscape Park of Knyszyńska Forest, while the rest, that is $522.55 \mathrm{~km}^{2}$ is occupied by the buffer zone of the Park. The area of Knyszyńska Forest within the Park together with the buffer zone of the Park cover $1052.96 \mathrm{~km}^{2}$, which makes $83.1 \%$ of the area of the Knyszyńska Forest. The other area is taken by agriculturally used land $210.25 \mathrm{~km}^{2}(16.6 \%)$ and water $3.81 \mathrm{~km}^{2}(0.3 \%)$. The Knyszyńska Forest area is divided into 12 forest districts administered by seven Forest Divisions (Łaska 2006).

The deforested land within the area of Knyszyńska Forest in the $18^{\text {th }}$ century were subjected to reforestation in the years 1935-1994 (Fig. 1). The reforestation was performed mainly in the area under administration of Krynki and Waliły Forest Divisions in the south-eastern part, Żednia Forest Division in the south and Dojlidy Forest Division in the south and in the central part where this study was performed (Fig. 1).

\section{Methods of study}

The research material is a synthesis of the 15 year cycle of observations (1987-2001) in the Knyszyńska Forest. The analyses presented were performed on the basis of field observations and laboratory methods. The field study of plant communities was conducted in fertile oak-hornbeam habitats Tilio-Carpinetum Tracz. 1962 and MelittiCarpinetum Sokoł. 1971 em Czerw. 1978. The observations were carried out in the natural forms and secondary communities of a given vegetation circle (Schwickerath 1954). The syntaxonomy of the natural vegetation units was assumed after Matuszkiewicz (2001). Detail ecological and phytosociological characterisation of the natural and secondary communities, data on their geomorphological variation, geological and soil chemistry variation are given in Łaska (2006).

In the field the phytosociological study of plant communities followed by habitat identification of the plant patches was performed. The analyzed material consisted of 178 relevés, including 47 ones of the natural communities and 131 ones of secondary communities, including 59 of the post-clear-cutting communities and 72 of the secondary forest communities aged 30-59, representing the first generation of trees on the post-agricultural use land. The relevés were taken assuming the 6-point cover-abundance Braun-Blanquet scale, in the natural communities and secondary forest communities on the plots of the size of $400 \mathrm{~m}^{2}(20 \times 20 \mathrm{~m})$, while in the post-clear-cut commu- 

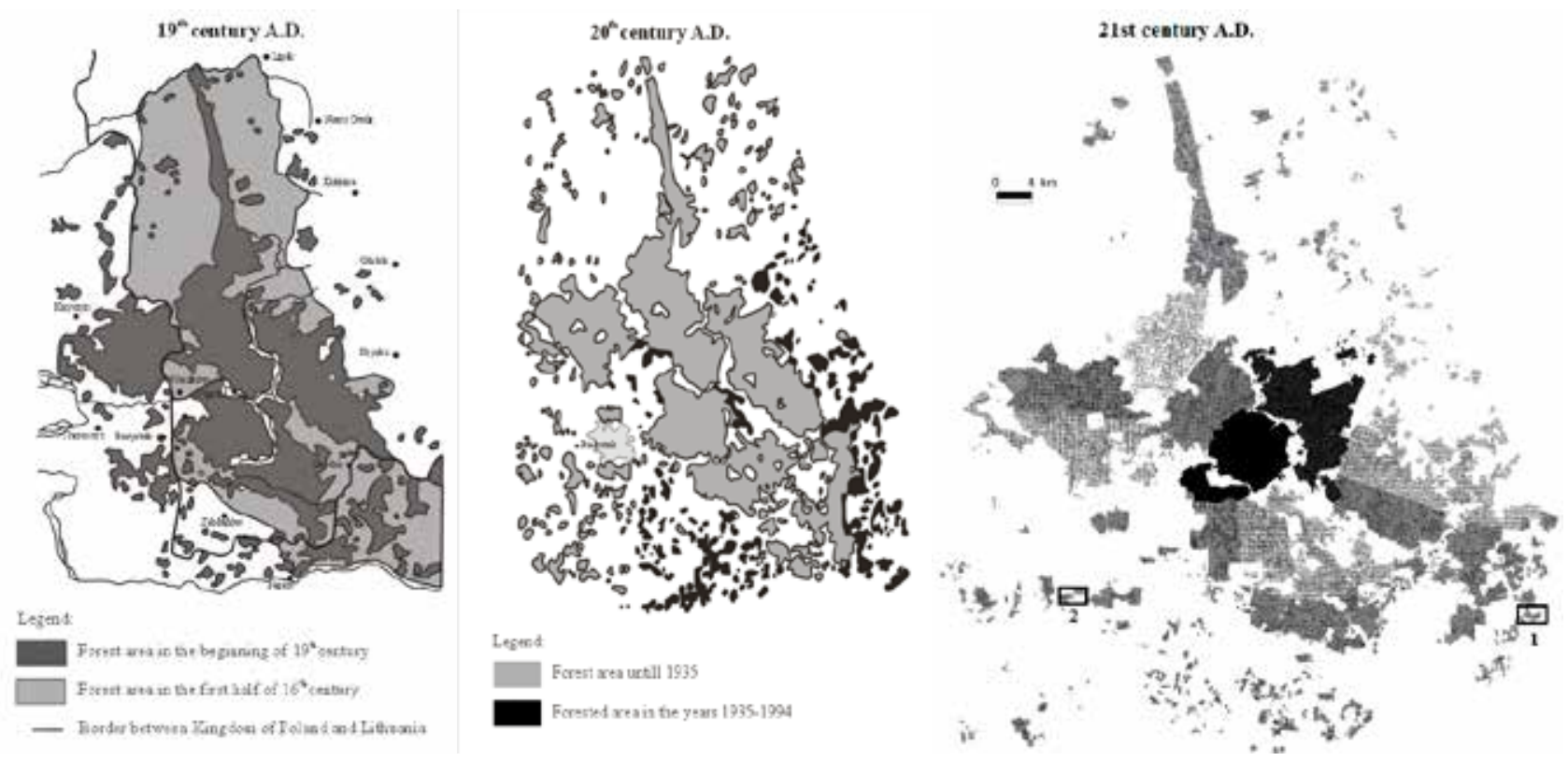

Figure 1. Changes of the forest areas of the Knyszyńska Forest form $16^{\text {th }}$ to $21^{\text {st }}$ century and localization of study area in the 1) Waliły Forest Division in the south-eastern part and 2) Dojlidy Forest Division in the south part (Source: Laska 2006, changed)

nities on the plots of $200 \mathrm{~m}^{2}(10 \times 20 \mathrm{~m})$. Qualitative and quantitative comparisons of the floristic composition were made on the basis of the synthetic features (Pawłowski 1972). The degree of plant communities degeneration was evaluated on the basis of the classification of phases of degeneration (quantitative changes) and forms of degeneration (qualitative changes) after Olaczek (1974).

The identification of habitats of the communities studied was made on the basis of the field study in the years 1994-2001, of the 14 soil profiles cut to the depth of $1.5 \mathrm{~m}$. Taxonomy of soil and nomenclature of soil levels were assumed after the standards of Polish Soil Science Society (Trzciński 1989). The classification into types and subtypes of humus was performed with the use of the ecological taxonomy of forest humus introduced by Prusinkiewicz (1994). Changes in the trophic character of the upper layers of soil and types of forest habitats were classified on the basis of the diagnostic scheme of the present state of fertility determined taking into account the stable and easily changing elements of habitat (Mąkosa et al. 1994).

In order to examine the changes in habitat of the communities studied, samples of the soil from the humus level (Ah) collected from the profiles were subjected to chemical analyses. The standard chemical properties of the accumulation horizon were determined by the standard procedures (Ostrowska et al. 1991; Mocek et al. 1997). The properties included specific density of soil, $\mathrm{pH}\left(\mathrm{pH}\right.$ in $\mathrm{H}_{2} \mathrm{O}, \mathrm{pH}$ in $\mathrm{KCl})$, contents of mineral components $\left(\mathrm{P}_{2} \mathrm{O}_{5}, \mathrm{~K}_{2} \mathrm{O}, \mathrm{Mg}\right.$, $\mathrm{Ca}$ in $\mathrm{mg}$ per $100 \mathrm{~g}$ of soil) organic carbon and nitrogen (C-org, N-org in \%), percentage content of humus and the
$\mathrm{C}: \mathrm{N}$ ratio. Analysis of these data permitted evaluation of the soil trophic state and its changes.

\section{Results}

\subsection{Ecological effects of deforestation and changes in the species composition and structure of plant communities}

As a result of deforestation (tree stand removal) the forest community is replaced by post-clear-cutting communities whose floristic composition and structure are much different from the natural oak-hornbeam community. The vertical structure is changed from the multilayer forest one into a monolayer structure of post-clear-cutting community. In the first stages of development, the post-clear-cutting communities show a variety of qualitative floristic compositions because of great significance of the non-forest components. The lack of trees and negligible density of the shrub layer promote development of non-forest vegetation. The herbal layer cover reaches $50-70 \%$, and in subsequent years it becomes the dominant structural element of these communities, reaching up to $100 \%$ cover. The species composition is much diverse, individual species prefer facial domination in the form of monospecies aggregations and patches. Besides the forest species, rich representations of post-clear-cutting species are found, of the class Epilobietea angustifolii (Rubus idaeus, Fragaria vesca, Chamaenerion angustifolium, Senecio sylvaticus), 
Table 1. Dynamic changes of species group in the particular development stages of the secondary communities from Tilio-Carpinetum and Melitti-Carpinetum circles after deforestation and spontaneously growing or afforestation on post-arable land

\begin{tabular}{|c|c|c|c|c|c|c|c|c|c|c|c|c|}
\hline \multirow{3}{*}{$\begin{array}{l}\text { Circle of communities } \\
\text { Type of community }\end{array}$} & \multicolumn{5}{|c|}{ Tilio-Carpinetum } & \multicolumn{7}{|c|}{ Melitti-Carpinetum } \\
\hline & \multirow[t]{2}{*}{$\begin{array}{c}\text { Natural } \\
\text { Tilio- } \\
\text { Carpinetum }\end{array}$} & \multicolumn{3}{|c|}{$\begin{array}{l}\text { Secondary communities } \\
\text { After deforestation } \\
\text { Post-clear-cutting }\end{array}$} & \multirow{2}{*}{$\begin{array}{c}\text { Afforestation } \\
\text { The secondary } \\
\text { forest } \\
\text { Pinus- } \\
\text { Vaccinium }\end{array}$} & \multirow[t]{2}{*}{$\begin{array}{c}\text { Natural } \\
\text { Melitti- } \\
\text { Carpinetum }\end{array}$} & \multicolumn{3}{|c|}{$\begin{array}{l}\text { Secondary communi } \\
\text { After deforestation } \\
\text { Post-clear-cutting }\end{array}$} & \multicolumn{3}{|c|}{$\begin{array}{c}\text { Spontaneously growing } \underset{\text { The secondary forest }}{\mid \text { Afforestation }} \\
\text { The }\end{array}$} \\
\hline & & stellarietosum & & calamagrostiet. & & & $\begin{array}{r}\text { Calan } \\
\text { rubetosum }\end{array}$ & $\begin{array}{l}\text { agrostietumarunc } \\
\text { agrostietosum }\end{array}$ & $\begin{array}{l}\text { dinaceae } \\
\text { deschampsiet. }\end{array}$ & $\begin{array}{c}\text { Populus- } \\
\text { Pulmonaria } \\
\end{array}$ & $\begin{array}{l}\text { Betula- } \\
\text { Festuca } \\
\end{array}$ & $\begin{array}{c}\text { Pinus- } \\
\text { Pleurozium }\end{array}$ \\
\hline Number of records & 25 & 8 & 18 & 6 & 32 & 22 & 16 & 6 & 5 & 16 & 7 & 17 \\
\hline Age of community & 110 & $2-6$ & $2-9$ & 1 & $42-59$ & 140 & $1-3$ & 2 & 8 & 45 & 40 & 30 \\
\hline \multirow{2}{*}{\multicolumn{13}{|c|}{ Systematical value of species group (D) }} \\
\hline \multirow{2}{*}{\multicolumn{11}{|c|}{$\begin{array}{l}\text { Syngenetic groups: } \\
\text { O. Fagetalia sylvaticae }\end{array}$}} & & \\
\hline & 26.59 & 12.3 & 4.73 & 4.55 & 0.04 & 8.29 & 3.55 & 3.54 & 3.01 & 10.44 & 1.64 & 0.02 \\
\hline $\begin{array}{l}\text { O. Quercetalia pubescenti-petraeae } \\
\text { Cl. Querco-Fagetea }\end{array}$ & 1224 & 7.54 & $-{ }_{3}^{-}$ & $-{ }^{-} 48$ & - & $\begin{array}{l}0.66 \\
5.81\end{array}$ & $\begin{array}{l}0.15 \\
5.06\end{array}$ & $\begin{array}{l}0.34 \\
137\end{array}$ & 251 & 2.37 & - & $\dot{-}$ \\
\hline & 38.71 & 19.7 & $\begin{array}{l}3.34 \\
8.04\end{array}$ & $\begin{array}{l}2.48 \\
7.03\end{array}$ & $\begin{array}{l}0.61 \\
0.57\end{array}$ & $\begin{array}{l}5.81 \\
14.23\end{array}$ & 5.06 & $\begin{array}{l}1.37 \\
5.07\end{array}$ & 2.51 & $\begin{array}{r}9.02 \\
21.66\end{array}$ & $\begin{array}{l}4.33 \\
5.65\end{array}$ & $\begin{array}{c}0.02 \\
0.245\end{array}$ \\
\hline Cl. Vaccinio-Piceetea & 9.27 & 1.37 & 0.3 & 6.98 & 16.46 & 6.66 & 2.19 & 4.72 & 3.36 & 3.55 & 14.8 & 17.83 \\
\hline Cl. Epilobietea angustifolii & 0.2 & 4.68 & 5.61 & 7.55 & 0.75 & 2.33 & 9.98 & 16.38 & 7.74 & 0.92 & - & 0.24 \\
\hline Cl. Molinio-Arrhenatheretea & 0.04 & 5.12 & 3.14 & 5.46 & 0.08 & 0.32 & 1.89 & 4.79 & 9.6 & 0.46 & - & 0.02 \\
\hline Cl. Nardo-Callunetea & & 0.88 & 1.82 & 4.55 & 1.47 & 0.15 & 1.63 & 6.03 & 4.92 & 0.23 & 8.47 & 2.89 \\
\hline Cl. Artemisietea vulgaris & 3.25 & 4.44 & 2.48 & 1.74 & & 2.47 & 4.49 & 4.71 & 2.68 & 0.89 & & - \\
\hline C1. Trifolio-Geranietea sanguinei & 0.13 & 0.34 & 1.48 & 0.46 & 0.06 & 0.67 & 0.54 & 1.01 & 2.43 & 1.45 & 1.88 & - \\
\hline Cl. Koelerio-Cornephoretea & 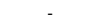 & 0.25 & 0.19 & 1.1 & - & 0.004 & 1.02 & 2.05 & 0.59 & - & 1.92 & 0.02 \\
\hline Cl. Stellarietea mediae & 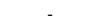 & 0.88 & 0.01 & 1.29 & & 0.43 & 2.89 & 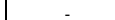 & 0.07 & 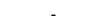 & & \\
\hline Cl. Rhamno-Prunetea & 0.05 & 0.05 & - & - & 0.08 & 0.36 & 0.13 & - & - & 0.07 & 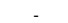 & 0.002 \\
\hline Cl. Festuco-Brometea & & & 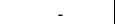 & 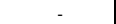 & & & & 0.08 & & & 2.76 & \\
\hline Accompanying species & 7.94 & 14.26 & 14.84 & 26.83 & 8.96 & 14.39 & 15.95 & 20.27 & 21.19 & 14.06 & 36.12 & 8.2 \\
\hline \multicolumn{13}{|c|}{ Summary values of cover coefficient (Wp) for syngenetic groups } \\
\hline \multirow{2}{*}{\multicolumn{13}{|c|}{\begin{tabular}{|l}
\multicolumn{1}{|c|}{ Syngenetic groups: } \\
O. Fagetalia sylvaticae \\
O. Ouercetalia pubescenti-petraeae
\end{tabular}}} \\
\hline & 13198 & 2451.25 & 2275.56 & 361.67 & 1.25 & 3730.91 & 1008.75 & $\begin{array}{r}266.67 \\
3.33\end{array}$ & 874 & 4226.88 & 81.43 & 1.18 \\
\hline $\begin{array}{l}\text { O. Quercetalia pubescenti-petraeae } \\
\text { Cl. Querco-Fagetea }\end{array}$ & 6089.33 & 5938.75 & 1391.67 & 183.33 & 255.63 & $\begin{array}{l}236.36 \\
3739.09\end{array}$ & $\begin{array}{c}34.38 \\
2226.88\end{array}$ & $\begin{array}{l}3.33 \\
93.33\end{array}$ & 2.3 & $\begin{array}{l}479.38 \\
6820.63\end{array}$ & 298.57 & 1.18 \\
\hline Cl. Querco-Fagetea (together) & 19287.33 & 8390 & 3667.23 & 545 & 256.88 & 7706.35 & 3270 & 363.33 & 876.3 & 11526.89 & 380 & 2.36 \\
\hline Cl. Vaccinio-Piceetea & 3590.67 & 725 & 364.44 & 615 & 15164.69 & 5256.36 & 223.13 & 3501.67 & 136 & 1773.75 & 4237.14 & 14692.35 \\
\hline Cl. Epilobietea angustifolii & 104 & 5211.25 & 3416.11 & 6276.67 & 191.88 & 701.36 & 6459.38 & 2610 & 1784 & 407.5 & - & 4.12 \\
\hline Cl. Molinio-Arrhenatheretea & 1.33 & 2586.25 & 1141.11 & 700 & 1.88 & 52.27 & 236.88 & 441.67 & 6156 & 6.25 & - & 309.41 \\
\hline Cl. Nardo-Callunetea & & 1630 & 2505 & 2021.67 & 289.69 & 5.91 & 1730.63 & 4168.33 & 2034 & 33.75 & 947.14 & 1318.82 \\
\hline Cl. Artemisietea vulgaris & 980.67 & 913.75 & 1627.78 & 185 & - & 340.45 & 1001.25 & 433.33 & 122 & 169.38 & - & - \\
\hline Cl. Trifolio-Geramietea sanguinei & 36 & 6.25 & 461.67 & 10 & 1.88 & 106.82 & 180 & 173.33 & 28 & 541.25 & 398.57 & \\
\hline Cl. Koelerio-Corynephoretea & - & 3.75 & 57.22 & 630 & - & 0.45 & 75 & 175 & 8 & - & 325.71 & 2.35 \\
\hline Cl. Stellarietea mediae & - & 10 & 0.56 & 8.33 & & 6.36 & 298.75 & - & 2 & - & & \\
\hline Cl. Rhamno-Prunetea & 2 & 2.5 & - & - & 1.88 & 48.64 & 2.5 & - & - & 2.5 & - & 1.18 \\
\hline Cl. Festuco-Brometea & & & & & & & & 1.67 & & & 8.57 & \\
\hline Accompanying species & 4724 & 4445 & 5423.33 & 4930 & 1821.25 & 7119.09 & 7621.25 & 6218.33 & 13424 & 8012.5 & 10938.57 & 281.18 \\
\hline \multicolumn{13}{|c|}{ Degener ative phases } \\
\hline Number of species in record & 86 & 113 & 115 & 92 & $\frac{564}{64}$ & 121 & 104 & 55 & 95 & 101 & 38 & 41 \\
\hline $\mathrm{Nur}$ & 49 & 37 & 25 & 8 & 10 & 39 & 16 & 8 & 13 & 44 & 6 & 2 \\
\hline Number of allophytes (A) & 37 & 76 & 90 & 84 & 54 & 82 & 88 & 47 & 82 & 57 & 32 & 39 \\
\hline Ratio (E):(A) (\%) & 132.43 & 48.7 & 27.8 & 9.5 & 18.5 & 47.56 & 18.2 & 17.02 & 15.85 & 77.2 & 18.8 & 5.1 \\
\hline Degener ative phase & & IV & IV & $\mathrm{v}$ & $\mathrm{v}$ & & $\mathrm{v}$ & $\mathrm{v}$ & $\mathrm{v}$ & III & $\mathrm{v}$ & $\mathrm{v}$ \\
\hline
\end{tabular}

meadow species of the class Molinio-Arrhenatheretea (Deschampsia caespitosa, Carex hirta, Vicia cracca, Dactylis glomerata), ruderal species of the class Artemisietea (Urtica dioica, Epilobium montanum, Cirsium arvense), species of sandy and oligotrophic grassland of the class KoelerioCorynephoretea (Rumex acetosella) or Nardo-Callunetea (Agrostis capillaries, Veronica officinalis) (Table 1). In the post-clear-cutting communities the sod formation processes take place in the soil, while floristic composition undergoes qualitative changes. They lead to impoverishment of the species composition, to excessive development of grasses (cespitization) or to penetration of apophytes into the communities (apophytization). The patches of natural oak-hornbeam communities are characterised by high contribution of eutrophic oak-hornbeam species from the order Fagetalia and mesotrophic species from the class Querco-Fagetea (Table 1).

As a consequence of deforestation, the forest community is replaced by post-clear-cutting community whose floristic composition and direction of further changes in vegetation depends to a high degree on the conditions of the habitat and floristic composition of the natural communities. After clear-cutting, the eutrophic habitats of Tilio-Carpinetum are covered by developing post-clear-cutting herbaceous vegetation Rubetum idaei Pfeiff. 1936 em. Oberd. 1973, with the dominant wild raspberry (Table 1). In the area of the Knyszyńska Forest, the Rubetum idaei communities from the Tilio-Carpinetum circle occur on the plains supported by glacial till of ground moraine at the foot of hills. In the mesotrophic habitats of Melitti-Carpinetum, the post-clear-cutting communities Calamagrostietum arundinaceae with the reed grass dominant were identified (Table 1). These are the post-clear-cutting graminaceous communities related to the mesotrophic habitats on medium acidic soil on the underlying gravel-sandy substratum.

The post-clear-cutting herbaceous communities Rubetum idaei were characterised on the basis of 32 relevés, while those of Calamagrostietum arundinaceae - on the basis of 27 relevés, 59 relevés in total (Table 1). The floristic compositions of these two communities are dominated by eutrophic oak-hornbeam species form the order Fagetalia and mesotrophic species from the class Querco-Fagetea, occurring together with a group of post-clearcutting species from the class Epilobietea angustifolii, and less represented coniferous forest species from the class Vaccinio-Piceetea. The patches of Rubetum idaei are distinguished by a numerous group of eutrophic oak-hornbeam species from the order Fagetalia (Isopyrum thalictroides, Asarum europaeum, Corydalis cava, C. solida, Dentaria bulbifera, Ficaria verna, Impatiens noli-tangere) and mesotrophic species from the class Querco-Fagetea (Fraxinus excelsior, Campanula trachelium), whose presence was not found in the community of Calamagrostietum arundinaceae. The group of eutrophic from the order 
Fagetalia has a diagnostic role in Rubetum idaei, because of much higher constancy and coverage than in Calamagrostietum arundinaceae. It is also confirmed by analysis of synthetic features (Table 1). In Rubetum idaei communities the value of the systematic group of species " $D$ " and total values of coverage with oak-hornbeam species from the order Fagetalia and class of Querco-Fagetea are much higher than in the community Calamagrostietum arundinaceae (Table 1).

\subsection{Classification of the phases of degeneration in post-clear-cutting communities}

Classification of the phases of degeneration in post-clearcutting communities has shown that the degree of their degeneration depends largely on the age of these communities (time after deforestation), on the habitat and floristic composition in the natural communities. The greatest changes in floristic composition of phytocenoses take place in the youngest developmental stages of post-clear-cutting communities (1 to 3 year old), usually in degeneration phase V (Table 1). In the 1-year post-clear-cutting community of Rubetum calamagrostietosum in the Tilio-Carpinetum habitats, the ratio of euphytes ( 8 species) to allophytes (84 species) was very low (9.5\%, degeneration phase V), similarly as for the 1-year old community of Calamagrostietum rubetosum in Melitti-Carpinetum habitats (18.2\%, degeneration phase V) (Table 1). It is related to the disappearance of species of narrow ecological amplitude, the species characteristic of the association and alliance and to a considerably smaller number of species of wide ecological amplitude, characteristic of the class, which is equivalent to the disappearance of the most stable elements of the former community. With development of post-clear-cutting communities, when they are 3-10 years old, the developing layer of bushes and deterioration of light accessibility to non-forest vegetation, the contribution of the species characteristic of oak-hornbeam habitats (euphytes) increases, while the post-clear-cutting communities occur in degeneration phase IV (Table 1).

\subsection{The effect of deforestation on soil conditions}

Removal of trees (deforestation) causes far reaching changes in the whole forest ecosystem. The changes occur not only in the structure and species composition of plant communities, but also in the structure and chemical composition of soil. Changes in the soil conditions in the secondary communities relative to those in the corresponding natural ones have most often concerned (Table 2): formation of the ploughing horizon (Ap), formation of transitional and mixed levels, enhanced gleying processes in the conditions of excessive moisture content, enhanced processes of precipitation and ground gleying, intensification of leaching of mineral components (base cations) from the top soil layers, intensification of the washing processes, involving migration of salts, mainly carbonates and clay minerals washed out from top levels into deeper ones, intensification of the podsolization processes involving washing out of the basic components, humic acids and iron and aluminium compounds from top levels into deeper ones.

After deforestation the soil of post-clear-cutting communities from the Tilio-Carpinetum circle was characterised on the basis of 4 soil profiles (2-5) and compared with the soil from the natural oak-hornbeam community (profile 1) (Table 2). In the natural community of typical oak-hornbeam forest Tilio-Carpinetum, profile 1, the gleyed brown soil was found, while in the post-clear-cutting communities of Rubetum, a year after deforestation, the presence of typical brown acidic soil was found, profiles $4-5$, in the 5 -year old post-clear-cutting community Rubetum agrostietosum, profile 2, there was typical brown soil and in the 9-year old post-clear-cutting community Rubetum agrostietosum, profile 3, there was typical rusty soil (Table 2).

Typical gleyed brown soil of the natural community Tilio-Carpinetum with 110 year old tree stand, was formed of silty light loamy sands on ice-dam lacustrine silts (Table 2). In the upper part of the soil profile $\mathrm{Ol}-\mathrm{Ah}-\mathrm{Bbrg}$ - BbrCg - $\mathrm{Cg}$ (profile 1) non-decomposed leaf litter was found $(\mathrm{Ol})$ in a horizon of small thickness $(0-0.5 \mathrm{~cm})$. There was also ectohumus of mull type. In the whole thickness of this type of soil, the horizons of browning (Bbrg), transitional $(\mathrm{BbrCg})$ and parent rock $(\mathrm{Cg})$ show the features of gleying, which affects the chemical properties of this soil and in particular its $\mathrm{pH}$ which in the upper part of the profile reaches 4.2 in $\mathrm{H}_{2} \mathrm{O}$ and 3.7 in $\mathrm{KCl}$ (Fig. 2).

One year after deforestation, in one-year old post-clearcutting communities of Rubetum the subtypes of typical acidic brown soil of the genetic levels $\mathrm{Ol}-\mathrm{Ofh}-\mathrm{Ap}-\mathrm{Bbr}$ - C1 - IIC2 - IIC3 (profile 4) and Ap - Bbr - IIC (profile 5) were identified, which evidenced considerable changes in the soil environment. The changes include: transformation of humus type from mull into moder (profile 4) or destruction of the upper soil levels (profile 5), presence of ploughing horizon (Ap) and washing out of carbonates from the whole thickness of genetic levels (Table 2). The soils in these communities are acidic in the upper part of the profile of low $\mathrm{pH}$, in $\mathrm{H}_{2} \mathrm{O}(3.41-3.97)$ and in $\mathrm{KCl}$ (3.15-3.45) (Fig. 2). The $\mathrm{pH}$ of a given soil is the lower than the shorter period from the clear-cutting, which is related to the washing out of mineral components from the upper layers of the soil by direct effect of precipitations. It can be assumed that $\mathrm{pH}$ of soils varies with time and has its own dynamics, increases in subsequent stages of vegetation development after clear-cutting (Fig. 2).

Transformation of the mull type humus present in the natural communities into the moder type one in the acid- 
Table 2. Characterization of soil profiles under the plant communities from a) Tilio-Carpinetum and b) Melitti-Carpinetum circles

1. Gleyed brown soil - formed of silty light loamy sands on ice-dam lacustrine silts under the 110-years old natural community Tilio-Carpinetum

2. Typical brown soil - formed of loamy sands on ice-dam lacustrine silts under the 5-years old post-clear-cutting community Rubetum agrostietosum

3. Proper rusty soil - formed of sands and gravels under the 9-years old post-clear-cutting community Rubetum agrostietosum

4. Typical brown acidic soil - formed of loamy sands with ferruginous deposition in all profile on glacial till of ground moraine under the 1-year old post-clear-cutting community Rubetum agrostietosum

5. Typical brown acidic soil - formed of heavy loamy sands on glacial till of ground moraine under the 1-year old post-clear-cutting community Rubetum idaei

6. Typical lessivé soil - formed of loamy sands on glacial till of ground moraine under the 42-years old secondary forest community Pinus-Vaccinium

7. Gleyed lessivé soil - formed of loamy sands on glacial till of ground moraine under the 59-years old secondary forest community Pinus-Vaccinium

\begin{tabular}{|c|c|c|c|c|c|c|c|c|c|c|c|c|c|c|}
\hline \multirow{3}{*}{\begin{tabular}{|c}
$\begin{array}{c}\text { Type } \\
\text { community }\end{array}$ \\
$\begin{array}{c}\text { Profile } \\
\text { number }\end{array}$ \\
\end{tabular}} & \multirow{3}{*}{\multicolumn{2}{|c|}{$\begin{array}{c}\text { Natural } \\
\text { Tilio-Carpinetum } \\
\mathbf{1 .}\end{array}$}} & \multicolumn{12}{|c|}{ Secondary communities } \\
\hline & & & \multicolumn{8}{|c|}{ After deforestation } & \multicolumn{4}{|c|}{ Forestation on post-arable land } \\
\hline & & & \multicolumn{2}{|c|}{2.} & \multicolumn{2}{|c|}{3.} & \multicolumn{2}{|c|}{4.} & \multicolumn{2}{|c|}{5.} & \multicolumn{2}{|c|}{6.} & \multicolumn{2}{|c|}{7.} \\
\hline & $\begin{array}{c}\text { Soil } \\
\text { horizon }\end{array}$ & $\begin{array}{c}\text { Depth } \\
(\mathrm{cm})\end{array}$ & $\begin{array}{c}\text { Soil } \\
\text { horizon }\end{array}$ & $\begin{array}{c}\text { Depth } \\
(\mathrm{cm})\end{array}$ & $\begin{array}{c}\text { Soil } \\
\text { horizon }\end{array}$ & $\begin{array}{c}\text { Depth } \\
(\mathrm{cm})\end{array}$ & $\begin{array}{c}\text { Soil } \\
\text { horizon }\end{array}$ & $\begin{array}{c}\text { Depth } \\
(\mathrm{cm})\end{array}$ & $\begin{array}{c}\text { Soil } \\
\text { horizon }\end{array}$ & $\begin{array}{c}\text { Depth } \\
(\mathrm{cm})\end{array}$ & $\begin{array}{c}\text { Soil } \\
\text { horizon }\end{array}$ & $\begin{array}{c}\text { Depth } \\
(\mathrm{cm})\end{array}$ & $\begin{array}{c}\text { Soil } \\
\text { horizon }\end{array}$ & $\begin{array}{c}\text { Depth } \\
(\mathrm{cm})\end{array}$ \\
\hline & $\mathrm{Ol}$ & $0,5-0$ & Olf & $3-0$ & Olf & $4-1$ & $\mathrm{Ol}$ & $7-2$ & Ap & $0-20$ & $\mathrm{Ol}$ & $10-7$ & $\mathrm{Ol}$ & $7-4$ \\
\hline & Ah & $0-7,5$ & $\mathrm{Ah}$ & $0-18$ & $\mathrm{Oh}$ & $1-0$ & Ofh & $2-0$ & Bbr & $20-55$ & Of & $7-3$ & Of & $4-2$ \\
\hline & Bbrg & 7,5-35 & Bbr & $18-52$ & Ap & $0-20$ & Ap & $0-12$ & II C & $55-150$ & $\mathrm{Oh}$ & $3-0$ & $\mathrm{Oh}$ & $2-0$ \\
\hline & $\mathrm{BbrCg}$ & $35-60$ & II $\mathrm{C}_{\mathrm{Ca}}$ & $52-100$ & $\mathrm{Bv}$ & 20-39 & Bbr & $12-33$ & & & Ap & $0-18$ & Ap & $0-8$ \\
\hline & $\mathrm{Cg}$ & $60-150$ & & & $\mathrm{BvC}$ & $39-64$ & $\mathrm{C} 1$ & $33-91$ & & & Eet & $18-36$ & Eetg & 21-sie \\
\hline & & & & & & & II C2 & $91-101$ & & & $\mathrm{Bt}$ & $36-50$ & Btgg & $21-33$ \\
\hline & & & & & & & II C3 & $101-150$ & & & $\mathrm{C}$ & $50-120$ & II C1gg & $33-108$ \\
\hline & & & & & & & & & & & II C $\mathrm{Ca}_{\mathrm{Ca}} \mathrm{g}$ & $120-190$ & II C2 $2_{\mathrm{Cagg}}$ & $108-200$ \\
\hline
\end{tabular}

b)

8. Leached brown soil - formed of sands, gravels and boulders of kame ice-crack accumulation under the 140-years old natural community Melitti-Carpinetum

9. Leached brown soil - formed of sands, gravels and boulders of kame ice-crack accumulation under the 1-year old post-clear-cutting community Calamagrostietum rubetosum 10. Proper rusty soil - formed of weakly loamy sands and loose sands under the 2-years old post-clear-cutting community Calamagrostietum agrostietosum

11. Leached brown soil - formed of light loamy sands and heavy loamy sands under the 8-years old post-clear-cutting community Calamagrostietum deschampsietosum

12. Leached brown soil - formed of weakly loamy sands and loose sands under the 45 -years old secondary forest community Populus-Pulmonaria

13. Leached brown soil - formed of weakly loamy sands and light loamy sands under the 40 -years old secondary forest community Betula-Festuca

14. Typical brown acidic soil - formed of light loamy sands and weakly loamy sands under the 30 -years old secondary forest community Pinus-Pleurozium

\begin{tabular}{|c|c|c|c|c|c|c|c|c|c|c|c|c|c|c|}
\hline \multirow{3}{*}{\begin{tabular}{|c|}
$\begin{array}{c}\text { Type } \\
\text { community }\end{array}$ \\
$\begin{array}{c}\text { Profile } \\
\text { number }\end{array}$ \\
\end{tabular}} & \multirow{3}{*}{\multicolumn{2}{|c|}{$\begin{array}{c}\text { Natural } \\
\text { Melitti-Carpinetum } \\
\mathbf{8} .\end{array}$}} & \multicolumn{12}{|c|}{ Secondary communities } \\
\hline & & & \multicolumn{6}{|c|}{ After deforestation } & \multicolumn{4}{|c|}{ Spontaneously growing on post-arable land } & \multirow{2}{*}{\multicolumn{2}{|c|}{$\begin{array}{c}\begin{array}{c}\text { Forestation on } \\
\text { on post-arable land }\end{array} \\
\mathbf{1 4} .\end{array}$}} \\
\hline & & & \multicolumn{2}{|c|}{9.} & \multicolumn{2}{|c|}{10.} & \multicolumn{2}{|c|}{11.} & \multicolumn{2}{|c|}{12.} & \multicolumn{2}{|c|}{13.} & & \\
\hline & $\begin{array}{c}\text { Soil } \\
\text { horizon }\end{array}$ & $\begin{array}{l}\text { Depth } \\
(\mathrm{cm})\end{array}$ & $\begin{array}{c}\text { Soil } \\
\text { horizon }\end{array}$ & $\begin{array}{c}\text { Depth } \\
(\mathrm{cm})\end{array}$ & $\begin{array}{c}\text { Soil } \\
\text { horizon }\end{array}$ & $\begin{array}{c}\text { Depth } \\
(\mathrm{cm})\end{array}$ & $\begin{array}{c}\text { Soil } \\
\text { horizon }\end{array}$ & $\begin{array}{c}\text { Depth } \\
(\mathrm{cm})\end{array}$ & $\begin{array}{c}\text { Soil } \\
\text { horizon }\end{array}$ & $\begin{array}{c}\text { Depth } \\
(\mathrm{cm})\end{array}$ & $\begin{array}{c}\text { Soil } \\
\text { horizon }\end{array}$ & $\begin{array}{c}\text { Depth } \\
(\mathrm{cm})\end{array}$ & $\begin{array}{c}\text { Soil } \\
\text { horizon }\end{array}$ & $\begin{array}{c}\text { Depth } \\
(\mathrm{cm})\end{array}$ \\
\hline & Olf & $0,5-0$ & A & $0-5$ & $\mathrm{ApBv}$ & $0-30$ & Ap & $0-18$ & Olf & $1-0$ & Olf & $0-1$ & $\mathrm{Ol}$ & $4-2$ \\
\hline & $\mathrm{Ah}$ & $0-10$ & $\operatorname{Bbr}(\mathrm{t}, \mathrm{fe})$ & $5-25$ & Stones & $30-32$ & $\operatorname{Bbr}(\mathrm{t}, \mathrm{fe})$ & $18-45$ & Ap & $0-25$ & Ap & $0-15$ & Of & $2-1$ \\
\hline & $\operatorname{Bbr}(\mathrm{t}, \mathrm{fe})$ & $10-50$ & Stones & $25-27$ & Bvre & $32-70$ & $\mathrm{Bbr}$ & $45-130$ & $\mathrm{Bbr}$ & $25-130$ & $\operatorname{Bbr}(\mathrm{t}, \mathrm{fe})$ & $15-33$ & $\mathrm{Oh}$ & $1-0$ \\
\hline & Stones & $50-52$ & Bbrre & $27-120$ & $\mathrm{C}$ & $70-150$ & C & $130-150$ & $\mathrm{C}$ & $130-150$ & $\mathrm{Bbr}$ & $33-82$ & Ap & $0-21$ \\
\hline & $\begin{array}{l}\text { II Bbrre } \\
\text { II C C }\end{array}$ & $\begin{array}{c}52-110 \\
110-150\end{array}$ & II $\mathrm{C}_{\mathrm{Ca}}$ & $120-150$ & & & & & & & $\mathrm{C}$ & $82-200$ & $\begin{array}{c}\mathrm{Bbr} \\
\mathrm{C}\end{array}$ & $\begin{array}{c}21-56 \\
56-150\end{array}$ \\
\hline
\end{tabular}

ic brown soil typical of post-clear-cutting communities is related to the presence of well-developed organic horizons of thickness reaching $5 \mathrm{~cm}$, mainly the sublevel Ol (Table 2). The presence of moder type humus indicates a low rate of organic matter decomposition and accumulation of acidic and little active humus in the top soil horizons. The presence of ploughing horizon (Ap) of the thickness from $12 \mathrm{~cm}$ (profile 4) to $20 \mathrm{~cm}$ (profile 5) in post-clear-cutting communities is a result of full tillage. Similar transformations of soil after removal of trees from a typical oak-hornbeam habitat were also noted in the typical rusty soil (Olf - Oh - Ap - Bv - BvC - IIC) of Rubetum community (profile 3) (Table 2).

After deforestation the soil in the post-clear-cutting community from the Melitti-Carpinetum circle, was characterised on the basis of 3 soil profiles (profiles 9-11) and compared with the soil from the natural Melitti-Carpinetum community (profile 8) (Table 2). In the natural community of Melitti-Carpinetum the presence of leached brown soil was found, (profile 8), similarly as in the post-clear-cutting communities in one year after clear-cutting (profile 9) and in the 8-year old community of Calamagrostietum (profile 11). The only exception is the typical rusty soil in the 2-year old post-clear-cutting community of Calamagrostietum (profile 10) (Table 2).

In the leached brown soil: Olf - Ah - Bbr(t, fe) - IIBbrre - IIC $_{\mathrm{Ca}}$ under the 140-years old natural community of Melitti-Carpinetum (profile 8), the moder type humus, typical of mesotrophic habitats of mixed forests, was found. It is brown periglacial soil of polygenetic origin is formed of sands, gravels and boulders of kame ice-crack accumulation (Table 2).

The changes observed in the soil of secondary communities were found to be the greater the younger the secondary community so the shorter the time from clear-cutting. In the leached typical brown soil: $\mathrm{A}-\mathrm{Bbr}(\mathrm{t}, \mathrm{fe})-\mathrm{Bbrre}$ - $\mathrm{IIC}_{\mathrm{Ca}}$ of the one-year old community of Calamagrostietum (profile 9) the organic horizon was missing as it had been destroyed by clear-cutting (Table 2). The next accumulation horizon (A) was also degraded, its thickness was reduced to about $5 \mathrm{~cm}$ and it was composed of weakly humufied sand of reduced content of humus. The much lower 


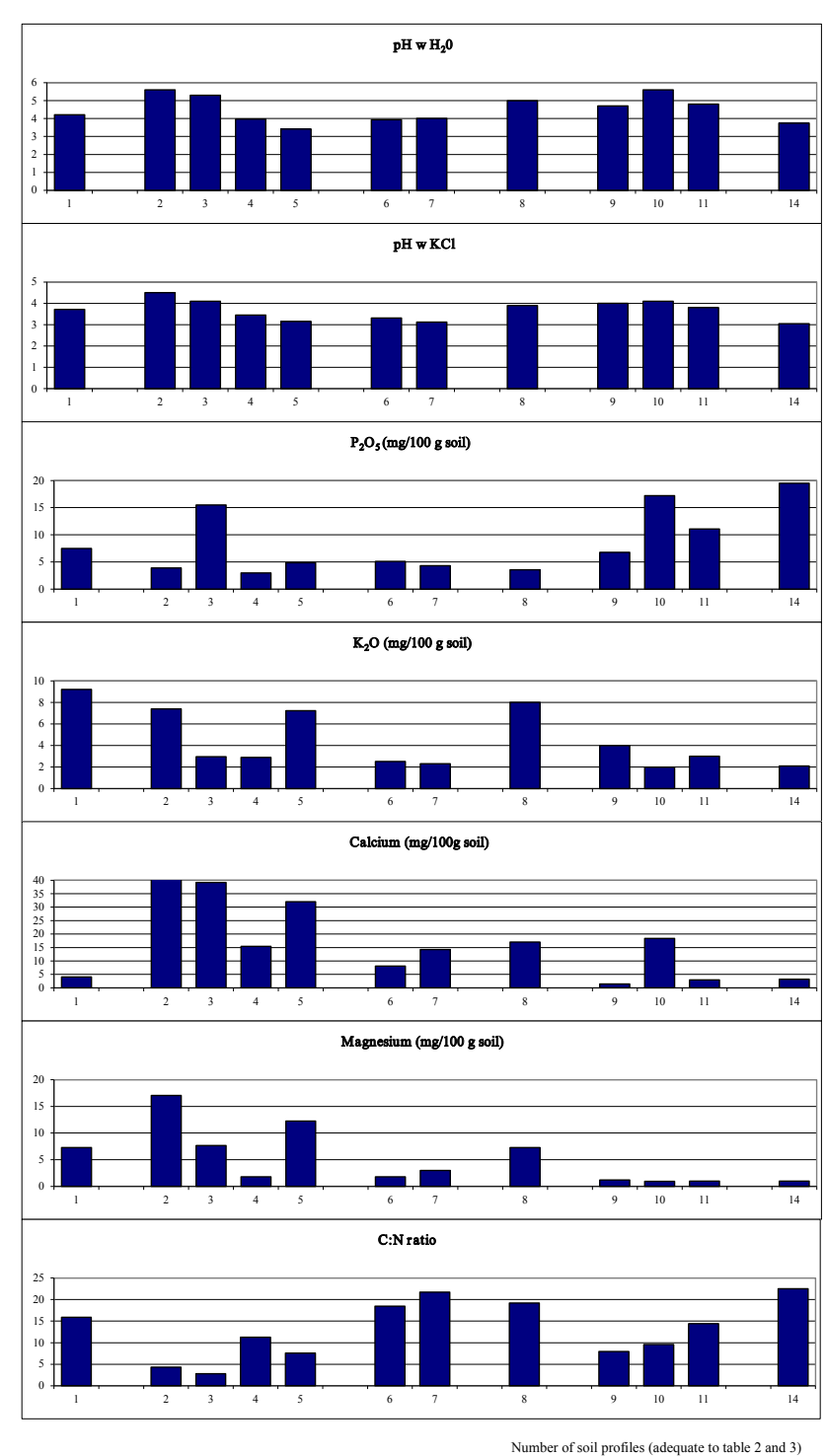

Figure 2. Differentiation of chemical properties of the humus level $(\mathrm{Ah})$ in the oak-hornbeam habitats of Tilio-Carpinetum and Melitti-Carpinetum

carbon to nitrogen ration of 7.93 in the accumulation horizon with respect to that in the soil of the natural community of 19.2 points to a fast process of mineralisation of organic substance on the open area left after clear-cutting (Fig. 2).

Transformations of soil environment as a result of forest management procedures in the typical rusty soil $(\mathrm{ApBv}$ - Bvre - C) under the two-year old community of Calamagrostietum agrostietosum (profile 10) and in the leached typical brown soil $(\mathrm{Ap}-\mathrm{Bbr}(\mathrm{t}, \mathrm{fe})-\mathrm{Bbr}-\mathrm{C})$ under the eight-year old post-clear-cutting community of Calamagrostietum deschampsietosum (profile 11) were manifested as destruction of the organic horizons $(\mathrm{O})$ by full ploughing and development of the ploughing horizon at the top soil layer (Ap, profile 11) or transition level (ApBv, profile 10), of rather great thickness $(18-30 \mathrm{~cm})$ (Table 2).

To sum up, the changes in soil conditions after removal of tree stands are the main reason for impoverishment of the top soil horizons in basic compounds and an increase in their acidity. Moreover, they lead to destruction of the organic horizons $(\mathrm{O})$ as a result of full ploughing or to transformation of humus by one typological degree. The genetic horizons of the soils after clear-cutting evidence a considerable simplification of the soil profile structure with respect to that in the soils of the natural communities.

\subsection{The effect of deforestation on transformations of oak-hornbeam habitats}

The forest habitat types classified in the study with the use of the diagnostic scheme of the present state of fertility, determined taking into account the stable and easily changing elements of habitat, indicate that in the oak-hornbeam natural communities Tilio-Carpinetum on potentially natural habitats (labelled as N), functioning in the unchanged species composition of tree-stands and unchanged character of herbal layer, the easily changeable and stable elements of habitats ecologically corresponded to each other. The mull type humus is formed in good habitat conditions on highly fertile and biologically active soil rich in mineral components. It is formed from leaf litter undergoing fast microbiological decomposition and humification, ectohumus is poorly developed and the organic horizon occurs only in the form of level Ol. It is characteristic of eutrophic habitats of fresh forest related to typical brown soil and its subtypes (Table 3). After deforestation the habitats of post-clear-cutting communities from the Tilio-Carpinetum circle are weakly degraded (labelled as d), which corresponds to weakly degraded fresh forest (Lśw-d) (Table 3). Transformations of these habitats include a change in the type of humus by 1 typological degree, from mull to moder (profiles 3-4), deformation of the soil profile by introduction of ploughing horizons (profiles 3-4) and damage of their organic horizons (profile 5) (Table 3). Evaluation of the current state of fertility of post-clear-cutting communities on eutrophic habitats has evidenced that they show the features of habitats by 2 typological degrees poorer (weakly degraded habitats) than the natural habitats not transformed by forest management procedures (Table 3).

The fertility of mesotrophic oak-hornbeam habitats Melitti-Carpinetum differs from that of eutrophic habitats because of different trophy and contents of nutrients. The moder type humus present in the natural state habitats of this type (labelled as N) shows properties intermediate between the mull type humus characteristic of eutrophic habitats of fresh forest and the mor type humus of oligotrophic coniferous habitats. The moder type humus is formed in the intermediate habitat conditions, in medium-fertile soil 
Table 3. Typological classification of the fertility degree of the oak-hornbeam habitats Tilio-Carpinetum and Melitti-Carpinetum ${ }^{*}$ explanations in the main text, chapter 4.4

\begin{tabular}{|c|c|c|c|c|c|c|}
\hline $\begin{array}{c}\text { Nr of } \\
\text { profiles }\end{array}$ & $\begin{array}{c}\text { Potential natural } \\
\text { vegetation }\end{array}$ & Type and community age & Soil subtype & Humus type & $\begin{array}{l}\text { Real form of } \\
\text { habitat fertility }\end{array}$ & $\begin{array}{c}{ }^{*} \text { Forest } \\
\text { habitat type }\end{array}$ \\
\hline \multicolumn{7}{|c|}{ Natural community } \\
\hline 1 & $\begin{array}{c}\text { Tilio- } \\
\text { Carpinetum }\end{array}$ & 110-years old natural community & $\begin{array}{l}\text { Gleyed brown } \\
\text { soil }\end{array}$ & Mull & $\begin{array}{l}\text { Natural habitat } \\
\text { (N) }\end{array}$ & Lśw-N \\
\hline \multicolumn{7}{|c|}{ After deforestation - post-clear-cutting community } \\
\hline 2 & $\begin{array}{c}\text { Tilio- } \\
\text { Carpinetum }\end{array}$ & $\begin{array}{c}\text { 5-years old post-clear- } \\
\text { cutting community Rubetum } \\
\text { agrostietosum }\end{array}$ & $\begin{array}{l}\text { Typical brown } \\
\text { soil }\end{array}$ & Mull & $\begin{array}{l}\text { Natural habitat } \\
\text { (N) }\end{array}$ & Lśw-N \\
\hline 3 & $\begin{array}{c}\text { Tilio- } \\
\text { Carpinetum }\end{array}$ & $\begin{array}{l}\text { 9-years old post-clear- } \\
\text { cutting community Rubetum } \\
\text { agrostietosum }\end{array}$ & $\begin{array}{l}\text { Proper rusty } \\
\text { soil }\end{array}$ & Moder & $\begin{array}{l}\text { Weakly degraded } \\
\text { habitat } \\
\text { (d) }\end{array}$ & Lśw-d \\
\hline 4 & $\begin{array}{c}\text { Tilio- } \\
\text { Carpinetum }\end{array}$ & $\begin{array}{c}\text { 1-year old post-clear- } \\
\text { cutting community Rubetum } \\
\text { agrostietosum }\end{array}$ & $\begin{array}{l}\text { Typical brown } \\
\text { acidic soil }\end{array}$ & Moder & $\begin{array}{l}\text { Weakly degraded } \\
\text { habitat } \\
\text { (d) }\end{array}$ & Lśw-d \\
\hline 5 & $\begin{array}{c}\text { Tilio- } \\
\text { Carpinetum }\end{array}$ & $\begin{array}{l}\text { 1-year old post-clear-cutting } \\
\text { community Rubetum idaei }\end{array}$ & $\begin{array}{l}\text { Typical brown } \\
\text { acidic soil }\end{array}$ & $\begin{array}{l}\text { Damage } \\
\text { of organic } \\
\text { horizons }\end{array}$ & $\begin{array}{l}\text { Weakly degraded } \\
\text { habitat } \\
\text { (d) }\end{array}$ & Lśw-d \\
\hline \multicolumn{7}{|c|}{ Forestation on post-arable land - secondary forest communities } \\
\hline 6 & $\begin{array}{c}\text { Tilio- } \\
\text { Carpinetum }\end{array}$ & $\begin{array}{l}\text { 42-years old secondary forest } \\
\text { community Pinus-Vaccinium }\end{array}$ & $\begin{array}{l}\text { Typical lessivé } \\
\text { soil }\end{array}$ & Mor & $\begin{array}{l}\text { Strongly degraded } \\
\text { habitat } \\
\text { (D) }\end{array}$ & Lśw-D \\
\hline 7 & $\begin{array}{c}\text { Tilio- } \\
\text { Carpinetum }\end{array}$ & $\begin{array}{l}\text { 59-years old secondary forest } \\
\text { community Pinus-Vaccinium }\end{array}$ & $\begin{array}{l}\text { Gleyed lessivé } \\
\text { soil }\end{array}$ & Mor & $\begin{array}{l}\text { Strongly degraded } \\
\text { habitat } \\
\text { (D) }\end{array}$ & Lśw-D \\
\hline \multicolumn{7}{|c|}{ Natural community } \\
\hline 8 & $\begin{array}{c}\text { Melitti- } \\
\text { Carpinetum }\end{array}$ & 140 -years old natural community & $\begin{array}{l}\text { Leached brown } \\
\text { soil }\end{array}$ & Moder & $\begin{array}{l}\text { Natural habitat } \\
\text { (N) }\end{array}$ & LMśw-N \\
\hline \multicolumn{7}{|c|}{ After deforestation - post-clear-cutting community } \\
\hline 9 & $\begin{array}{c}\text { Melitti- } \\
\text { Carpinetum }\end{array}$ & $\begin{array}{c}\text { 1-year old post-clear-cutting } \\
\text { community Calamagrostietum } \\
\text { rubetosum }\end{array}$ & $\begin{array}{l}\text { Leached brown } \\
\text { soil }\end{array}$ & $\begin{array}{l}\text { Damage } \\
\text { of organic } \\
\text { horizons } \\
\end{array}$ & $\begin{array}{l}\text { Deformed forest } \\
\text { habitat } \\
(\mathrm{z})\end{array}$ & LMśw-Z \\
\hline 10 & $\begin{array}{c}\text { Melitti- } \\
\text { Carpinetum }\end{array}$ & $\begin{array}{c}\text { 2-years old post-clear-cutting } \\
\text { community Calamagrostietum } \\
\text { agrostietosum }\end{array}$ & $\begin{array}{l}\text { Proper rusty } \\
\text { soil }\end{array}$ & $\begin{array}{l}\text { Damage } \\
\text { of organic } \\
\text { horizons }\end{array}$ & $\begin{array}{l}\text { Weakly degraded } \\
\text { habitat } \\
\text { (d) }\end{array}$ & LMśw-d \\
\hline 11 & $\begin{array}{l}\text { Melitti- } \\
\text { Carpinetum }\end{array}$ & $\begin{array}{c}\text { 8-years old post-clear-cutting } \\
\text { community Calamagrostietum } \\
\text { deschampsietosum }\end{array}$ & $\begin{array}{l}\text { Leached brown } \\
\text { soil }\end{array}$ & $\begin{array}{l}\text { Damage } \\
\text { of organic } \\
\text { horizons }\end{array}$ & $\begin{array}{l}\text { Deformed forest } \\
\text { habitat } \\
(\mathrm{z})\end{array}$ & LMśw-z \\
\hline \multicolumn{7}{|c|}{ Spontaneously growing on post-arable land - secondary forest communities } \\
\hline 12 & $\begin{array}{c}\text { Melitti- } \\
\text { Carpinetum } \\
\end{array}$ & $\begin{array}{l}\text { 45-years old secondary forest } \\
\text { community Populus-Pulmonaria }\end{array}$ & $\begin{array}{l}\text { Leached brown } \\
\text { soil }\end{array}$ & Moder & $\begin{array}{l}\text { Natural habitat } \\
(\mathrm{N})\end{array}$ & LMśw-N \\
\hline 13 & $\begin{array}{c}\text { Melitti- } \\
\text { Carpinetum }\end{array}$ & $\begin{array}{l}\text { 40-years old secondary forest } \\
\text { community Betula-Festuca }\end{array}$ & $\begin{array}{l}\text { Leached brown } \\
\text { soil }\end{array}$ & Moder & $\begin{array}{l}\text { Weakly degraded } \\
\text { habitat } \\
\text { (d) }\end{array}$ & LMśw-d \\
\hline \multicolumn{7}{|c|}{ Forestation on post-arable land - secondary forest communities } \\
\hline 14 & $\begin{array}{c}\text { Melitti- } \\
\text { Carpinetum }\end{array}$ & $\begin{array}{l}\text { 30-years old secondary forest } \\
\text { community Pinus-Pleurozium }\end{array}$ & $\begin{array}{l}\text { Typical brown } \\
\text { acidic soil }\end{array}$ & Mor & $\begin{array}{l}\text { Strongly degraded } \\
\text { habitat } \\
\text { (D) }\end{array}$ & LMśw-D \\
\hline
\end{tabular}


of medium content of mineral components. It is formed of leaf litter or leaf-needle litter undergoing slow pace decomposition and accumulated organic substance in the form of (Ol) and a characteristic subhorizon Of, made of comminuted fragments of plants of recognizable tissue structure (detritus). The moder type humus is typical of mesotrophic habitats of mixed forests in the natural state (profile 8) representing the old-tree forest of the natural oak-hornbeam association Melitti-Carpinetum (Table 3).

After deforestation the post-clear-cutting habitats from the Melitti-Carpinetum circle are deformed (labelled as z) or weakly degraded (labelled as d), which corresponds to the habitats of mixed fresh deformed forest (LMśw-z) or mixed fresh weakly degraded forest (LMśw-d) (Table 3). Transformations of these habitats concern the organic horizons of soil (profiles 9-11) and involve development of ploughing horizons (Ap) or ploughing-rusty horizons $(\mathrm{ApBv})$ which is related to full ploughing (profiles 10-11) (Table 3). Evaluation of the present fertility of post-clearcutting communities on mesotrophic habitats has shown that they represent the diagnostic features of habitats by one typological degree of fertility poorer (deformed habitats) or by two typological degrees poorer (weakly degraded habitats) than the natural habitats not transformed as a result of forest management procedures (Table 3).

\subsection{Ecological consequences of afforestation}

Secondary forest communities after afforestation represent phytocenoses of tree-stands compatible or incompatible with the habitat conditions. The degree of their deformation depends mainly on the habitat fertility and development of certain types of tree-stands with domination of different species. The type of habitats and the main edifiers of the tree layer determine the floristic composition of secondary communities studied and determine the directions of vegetation changes upon succession after clear-cutting. Identification of forest secondary communities forming the first generation of trees on the post-agricultural use land has shown that they develop as monolayer pine tree stands with the dominant Pinus sylvestris in the habitats from the Tilio-Carpinetum and Melitti-Carppinetum circles. They represent phytocenoses of high degree of anthropogenic transformations. Other dynamic changes on post-agricultural use land were noted as a result of abandonment of arable land on which spontaneous tree-stands developed with dominant trembling poplar Populus tremula or dominant Betula pendula, which were identified in oak-hornbeam habitats from the Melitti-Carppinetum circle. It has been established that degradation of phytocenoses increases depending on different procedures applied after intensive agricultural use period followed by land abandonment:

- Post-arable land was not artificially reforested with pine trees - leading to spontaneously developing forest secondary communities degenerated by apophytization (Populus-Pulmonaria);

- Post-arable land was not artificially reforested with pine trees but it was used as a pasture - leading to spontaneous development of secondary forest communities degenerated by cespitization (Betula-Festuca);

- Post-arable land was artificially reforested with pine trees - leading to secondary forest communities of tree-stands incompatible with the conditions of habitat, degenerated by bryophytization (Pinus-Vaccinium and Pinus-Pleurozium).

The smallest quantitative changes in the floristic composition and structure of phytocenoses on post-agricultural use land were observed in secondary forest community with spontaneously growing tree-stands being a chain link in the natural successions leading to reproduction of the original natural communities. These communities do not produce young trees of next generation and under their canopy the subcanopy layer of hornbeam, oak, linden and maple trees is abundantly developing. The young trees are able to form the dominant oak-hornbeam tree-stand in a short time. It happens mainly in secondary forest community with dominant aspen (Populus-Pulmonaria) in the habitats from the Melitti-Carpinetum circle, in the phase III of degeneration (Table 1). In the secondary forest community Populus-Pulmonaria the species characteristic of the class Querco-Fagetea are enriched with non-forest species but the general character of vegetation is little changed (Table 1). The floristic changes involve mainly an increased contribution of synanthropic species from the anthropogenically changed habitats, which points to apophytization as the main form of their degeneration.

Greater degeneration was observed when the post-arable land with spontaneously developing birch tree stand was also used as a pasture (Table 1). Spontaneous birch tree stand make a poorly compact canopy under which a layer of trees and shrubs of small cover develops. This means that the phytocenosis is strongly thinned and the herbal layer is dominated by grass. These changes lead to development of secondary communities with cespitization as the main form of degeneration (Betula-Festuca).

The greatest degeneration changes after reforesting of post-arable land were found in the monolayer homogeneous pine tree forests Pinus-Vaccinium from the Tilio-Carpinetum circle and Pinus-Pleurozium from the Melitti-Carpinetum circle (Table 1). These patches had been used as arable land and later after abandonment, they were artificially planted with pine trees. Intense agricultural use followed by planting pine trees in the oak-hornbeam forest habitats leads to gradual withdrawal or total phase out of the oak-hornbeam forest species and disappearance of even the most resistant species from the original community. These communities are the strongest transformed and represent phase $\mathrm{V}$ of degeneration (Table 1). After introduction of 
pine trees onto the post-arable land, the developing pine forest with compact canopy significantly restricts the development of species from lower layers permitting only the abundant growth of acidophilic undershrubs and moss, reaching the greatest coverage in such conditions, up to $80 \%$. A homogeneous pine tree stand and almost empty bottom of the forest with strongly developed bilberry and moss cover represent the secondary forest communities degenerated by the process of bryophytization (Pinus-Vaccinium and Pinus-Pleurozium).

\subsection{Afforestation and soil transformation}

The soil from the secondary forest community from the Tilio-Carpinetum circle was characterised on the basis of 2 soil profiles (6-7), while that from the Melitti-Carpinetum circle was characterised on the basis of 3 profiles (12-14) (Table 2).

In the secondary forest communities of Pinus-Vaccinium from the Tilio-Carpinetum circle making the first generation of trees on the post-arable land, the changes in soil conditions were very significant (Table 2, Fig. 2). The soil in the habitats of these communities is mainly strongly degraded typical lessivé soil. In the typical lessivé soil: $\mathrm{Ol}$ - Of - Oh - Ap - Eet $-\mathrm{Bt}-\mathrm{C}-\mathrm{IIC}_{\mathrm{Ca}} \mathrm{g}$ (profile 6) and in the gleyed lessivé soil: $\mathrm{Ol}-\mathrm{Of}-\mathrm{Oh}-\mathrm{Ap}-$ Eetg $-\mathrm{Btgg}-$ IIC1gg - IIC2 $2_{\mathrm{Ca}}$ gg (profile 7), the upper soil horizons were transformed by full ploughing into the ploughing horizon (Ap) of significant thickness (Table 2). The ectohumus of mor type present in these two types of soil, characteristic of coniferous forest habitats, contains thick layers of undecayed organic matter $(7-10 \mathrm{~cm})$ made of pine needles. Poor conditions of decomposition of organic matter lead to accumulation of acidic and little active humus in the subhorizon Of form, leading to acidification of the oak-hornbeam habitat and its oligotrophisation. In the upper part of the soil profile the $\mathrm{pH}$ values were acidic, equal to 3.9-4.0 in $\mathrm{H}_{2} \mathrm{O}$ and 3.1-3.3 in $\mathrm{KCl}$ (Fig. 2). The acidic substances forming in the process of humification are washed out by precipitation down into the profile, which is observed as podsolization processes of the upper part of soil (profile 6 , Ap horizon). The two types of soil also show strong features of gleying processes, typical lessivé soil (profile 6) processes of precipitation gleying, while gleyed lessivé soil (profile 7) shows processes of ground gleying (Table 2).

Significant soil transformations were also noted in the forest secondary communities from the Melitti-Carpinetum circle (Table 2). The leached proper brown soil (profiles 12-13) and typical acidic brown soil (profile 14) characteristic of this community are degraded and anthropogenically transformed as a result of the earlier agricultural use. In the soil studied the upper horizons are changed by full ploughing into a ploughing horizon (Ap) of a significant thickness $(15-25 \mathrm{~cm})$, the type of humus is changed and morphology of the profiles is simplified. They reveal the main three genetic horizons (Ap, Bbr and C). In the typical acidic brown soil $(\mathrm{Ol}-\mathrm{Of}-\mathrm{Oh}-\mathrm{Ap}-\mathrm{Bbr}-\mathrm{C})$ of a 30year old secondary forest community Pinus-Pleurozium (profile 14) there is ectohumus of mor type, characteristic of coniferous forest habitats and the earlier agricultural use of the land is manifested as a ploughing horizon below the humus (Ap) of the thickness $21 \mathrm{~cm}$ (Table 2).

\subsection{Afforestation and transformations of oak- hornbeam habitat transformations}

The forest habitat types classified by the diagnostic scheme of the present state of fertility have pointed out that the oak-hornbeam habitats in the secondary forest communities on post-agricultural use land are strongly degraded. In their soil the type of humus has been changed by three typological degrees, from mull to mor, when compared with the soil of the natural oak-hornbeam habitats.

The habitats of secondary forest communities from the Tilio-Carpinetum circle on post-arable land are strongly degraded (labelled as D) and correspond to those of strongly degraded fresh forest (Lśw-D) (Table 3). In the typical lessivé soil of secondary forest communities Pinus-Vaccinium (profiles 6-7), the upper soil horizons are transformed into the ploughing horizon (Ap). The ectohumus of mor type, typical for coniferous forest habitats, is by three classes of fertility lower than that of the mull type humus in the habitats of natural oak-hornbeam forests. From the diagnostic viewpoint it means that the fertility of these habitats has been by three typological degrees diminished (strongly degraded habitats).

Changes in the soil are similar to those observed in the eutrophic habitats of Tilio-Carpinetum were noted in the mesotrophic habitats of Melitti-Carpinetum. The habitats of secondary forest habitats on post-arable land are strongly degraded (labelled as D) and correspond to those in the mixed strongly degraded fresh forest (LMśw-D) (Table 3). In the typical acidic brown soil of a 30-year old pine forest Pinus-Pleurozium, the upper soil horizons were changed into a ploughing layer as a result of full ploughing (Ap) (profile 14). The ectohumus of mor type in the form of comminuted subhorizon Of was by three classes of fertility lower than the moder type humus in the natural habitats. From the diagnostic point of view, it indicates that the soil fertility of the secondary Melitti-Carpinetum habitats (strongly degraded) was decreased by three typological degrees of fertility. It leads to oligotrophisation of the Melitti-Carpinetum habitat and coniferous character of the secondary community. 


\section{Discussion and conclusions}

In the post-clear-cutting communities at the beginning of their development in the process of secondary succession there is practically no way to determine the final community (Thompson III \& DeGraaf 2001; Trani et al. 2001). Such a determination is more difficult to establish in short time after the clear-cutting (Wu et al. 2001; Allison et al. 2003; Hiromi et al. 2006). The character of the final community depends to a high degree on the habitat changes introduced by man as forest management procedures (Bell \& Newmaster 2002; Deal et al. 2002; Humphrey et al. 2004; Kern et al. 2006; Wu et al. 2008). The degree of disturbance of the post-clear-cutting communities is the greater the shorter the time from the deforestation when the clear-cutting was accompanied by other forest management measures (Chinea \& Helmer 2003; Haeussler \& Bergeron 2004; Rosenvald \& Lõhmus 2008). Such measures can be removal of the fallen tree trunks, preparation of the soil for reforestation or stamp pulling cause a number of significant changes in the phytoclimatic and edaphic qualities as well as in the floristic composition (Siira-Pietikäinen et al. 2001, 2003; Johnston \& Crossley 2002; Elliott \& Knoepp 2005). The disappearance of the most stable species building the patches of natural communities and change in the formation from forest to non-forest one classify the postclear-cutting communities as very strong disturbance (Łaska 2006). On the basis of the degree of disturbance of postclear-cutting communities, defined by the phases of degeneration, it should be noted that the eutrophic oak-hornbeam habitats are more resistant to invasion of foreign elements to the species composition of phytocenoses than the mesotrophic oak-hornbeam habitats.

After deforestation in the post-clear-cutting area a non-forest formation of vegetation develops and it occupies the area until the development of dense canopies of young trees which takes from a few to nearly 20 years, depending on the type of habitat and quality of new trees (Johnston \& Crossley 2002; Hiromi et al. 2006). Removal of the layer of trees that determine the functioning of the other layers in forest communities and their seasonal rhythms is the main cause of rapid changes in the ecological and habitat conditions in the area (Wright \& Coleman 2002; Kranabetter \& Coates 2004; Hannam et al. 2005). Total removal of trees causes rapid climatic changes, from the climate of forest to that of open space, which means changes in almost all climatic factors: light accessibility, thermal conditions and air humidity (Puchalski 2000). Changes in the climate are reflected in the changes in the habitat conditions, mainly the soil conditions, including their physical and chemical properties (Puchalski 2000; Johnston \& Crossley 2002; Hannam et al. 2005). The transpiration from the tree crowns as well as the uptake of water by the roots cease. As the water from deeper layers is used in smaller amount because it is no longer needed by tree roots, the water table of ground water can increase. When the ground water table is high, this process can lead to bog development or slurrying of the soil (Puchalski 2000). Other consequences can be a change in moisture content and initiation of gleying processes in the soils of excessive moisture content or increased intensity of processes of precipitation and ground gleying (Laska 2006). Also the structure and chemical composition of soil can be changed. The tree cutting, stamp pulling and other measures, the flocculated structure of the soil can be destroyed and transformed into the aliquoted-grained one, which can lead to washing out of the mineral components of the soil and impoverishment of its upper horizons (Puchalski 2000). Another type of changes induced by disturbances in the habitat conditions concern the cycle of matter. After removal of trees and undergrowth, the inflow of litter as the main source of organic matter is stopped and considerable amounts of organic substances are removed together with timber. The organic matter left on the post-clear-cutting area undergoes fast mineralisation under the influence of sunlight heat and the consequence is a significant decrease in the amount of humus of destruction of humus. Faster mineralisation of the litter and decreased amount of humus facilitate the washing out of mineral compounds by precipitations (Puchalski 2000; Ponge 2003).

In general, evaluation of the ecological consequences of deforestation and reforestation of post-arable land has shown that these procedures on the fertile habitats of deciduous forests lead to significant changes in the floristic composition and degradations of habitats (Łaska 2006; Matuszkiewicz 2013a, b). The changes include impoverishment of habitats, degradation of forest humus, deterioration of physical, chemical and biological properties of the top soil horizons. The final outcome of the changes is oligohrophisation of forest habitats (Łaska 2006). In view of the above, to protect the deciduous forests new methods for rational renovation and management of the fertile oak-hornbeam habitats should be searched for.

\section{References}

Allison T. D., Art H. W., Cunningham F. E. \& Teed R., 2003, Forty-two years of succession following strip clearcutting in a northern hardwoods forest in northwestern Massachusetts, Forest Ecology and Management 182: 285-301.

Bell F. W. \& Newmaster S. G., 2002, The effects of silvicultural disturbances on the diversity of seed-producing plants in the boreal mixedwood forest, Canadian Journal of Forest Research 32: 1180-1191.

Burke D. M., Elliott K. A., Holmes S. B. \& Bradley D., 2008, The effects of partial harvest on the understory 
vegetation of southern Ontario woodlands, Forest Ecology and Management 255: 2204-2212.

Chinea J. D. \& Helmer E. H., 2003, Diversity and composition of tropical secondary forests recovering from large-scale clearing: results from the 1990 inventory in Puerto Rico, Forest Ecology and Management 180: 227-240.

Deal R. L., 2001, The effects of partial cutting on forest plant communities of western hemlock-Sitka spruce stands in southeast Alaska, Canadian Journal of Forest Research 31: 2067-2079.

Deal L. R. \& Tappeiner J. C., 2002, The effects of partial cutting on stand structure and growth of western hemlock-Sitka spruce stands in southeast Alaska, Forest Ecology and Management 159: 173-186.

Deal R. L., Tappeiner J. C. \& Hennon P. E., 2002, Developing silvicultural systems based on partial cutting in western hemlock-Sitka spruce stands of southeast Alaska, Forestry 75: 425-431.

Elliott K. E. \& Knoepp J. D., 2005, The effects of three regeneration harvest methods on plant diversity and soil characteristics in the southern Appalachians, Forest Ecology and Management 211: 296-317.

Faliński J. B., 1972, Synantropizacja szaty roślinnej - próba określenia istoty procesu i głównych kierunków badań [Synantropization of vegetation - an attempt to define the essence of the process and the main directions of study], Phytocoenosis 1(3): 157-170.

Gilliam F. S., 2002, Effects of harvesting on herbaceous layer diversity of a central Appalachian hardwood forest in West Virginia, USA, Forest Ecology and Management 155: 33-43.

Haeussler S. \& Bergeron Y., 2004, Range of variability in boreal aspen plant communities after wildfire and clear-cutting, Canadian Journal of Forest Research 34: 274-288.

Hannam K. D., Quideau S. A., Kishchuk B. E., Oh S. W. \& Wasylishen R. E., 2005, Forest-floor chemical properties are altered by clear-cutting in boreal mixedwood forest stands dominated by trembling aspen and white spruce, Canadian Journal of Forest Research 35: 24572468.

Hiromi Y., Ito S., Mitsuda Y. \& Fukuzato K., 2006, Effects of topography and management history on natural forest recovery in abandoned forest after clear-cutting in Miyazaki, Japan, Journal of Forest Research 11: 99106. DOI 10.1007/s10310-005-0192-5.

Holgen P. \& Hanell B., 2000, Performance of planted and naturally regenerated seedlings in Picea abies-dominated shelterwood stands and clearcuts in Sweden, Forest Ecology and Management 127: 129-138.

Humphrey J. W., Peace A. J., Jukes M. R. \& Poulsom E. L., 2004, Multiple-scale factors affecting the development of biodiversity in UK plantations, [in:] Forest Biodiver- sity: Lessons from History for Conservation, O. Honnay, K. Verheyen, B. Bossuyt, M. Hermy (eds), CABI Publishing, Wallingford: 143-162.

Ito S., Nakayama R. \& Buckley G. P., 2004, Effect of previous land-use on plant species diversity in semi-natural and plantation forest in a warm-temperate region in southeastern Kyushu, Japan, Forest Ecology and Management 196: 213-225.

Jalonen J. \& Vanha-Majamaa I., 2001, Immediate effects of four different felling methods on mature boreal spruce forest understorey vegetation in southern Finland, Forest Ecology and Management 146: 25-34.

Johnston J. M. \& Crossley D. A., 2002, Forest ecosystem recovery in the southeast US: soil ecology as an essential component of ecosystem management, Forest Ecology and Management 155: 187-203.

Jones P. D., Edwards S. L, Demarais S. \& Ezell A. W., 2009, Vegetation community responses to different establishment regimes in loblolly pine (Pinus taeda) plantations in southern MS, USA, Forest Ecology and Management 257: 553-560.

Kern C. C., Palik B. J. \& Strong T. F., 2006, Ground-layer plant community responses to even-age and uneven-age silvicultural treatments inWisconsin northern hardwood forests, Forest Ecology and Management 230: $162-170$.

Kranabetter J. M. \& Coates K. D., 2004, Ten-year postharvest effects of silviculture systems on soil-resource availability and conifer nutrition in a northern temperate forest, Canadian Journal of Forest Research 34: 800-809.

Lindgren P. M. F. \& Sullivan T. P., 2001, Influence of alternative vegetation management treatments on conifer plantation attributes: abundance, species diversity, and structural diversity, Forest Ecology and Management 142: 163-182.

Łaska G., 2000, Dynamic processes in the secondary communities, Polish Association for Landscape Ecology, Warsaw Univ. Press, Warsaw: 160-171.

Łaska G., 2002, Anthropogenic changes of vegetation in the Knyszyńska Forest, Ecological Questions 1: 71-85.

Łaska G., 2006, Tendencje dynamiczne zbiorowisk zastępczych w Puszczy Knyszyńskiej [Dynamic tendencies of the secondary communities in the Knyszyńska Forest], Bogucki Wydawnictwo Nauk., Białystok-Poznań: 1-500.

MacDonald G. B. \& Thompson D. J., 2003, Responses of planted conifers and natural hardwood regeneration to harvesting, scalping, and weeding on a boreal mixedwood site, Forest Ecology and Management 182: 213-230.

Matuszkiewicz J. M., Kowalska A., Solon J., Degórski M., Kozłowska A., Roo-Zielińska E., Zawiska I. \& Wolski J., 2013a, Long-term evolution models of post-ag- 
ricultural forests, Prace geograficzne 240, Warszawa: 1-318.

Matuszkiewicz J. M., Kowalska A., Kozłowska A., Roo-Zielińska E. \& Solon J., 2013b, Differences in plant-species composition, richness and community structure in ancient and post-agricultural pine forests in central Poland, Forest Ecology and Management 310: 567-576.

Matuszkiewicz W., 2001, Przewodnik do oznaczania zbiorowisk roślinnych Polski [A guide to determine plant communities of Poland], PWN, Warszawa: 1-537.

Mąkosa K., Dzierzbicki J., Gromadzki A., Kliczkowska A. \& Krzyżanowski A., 1994, Zasady kartowania siedlisk leśnych [The principles forest habitat mapping], IBL, Warszawa: 1-121.

Mocek A., Drzymała S. \& Maszner P., 1997, Geneza, analiza i klasyfikacja gleb [Genesis, the analysis and classification of soils], Wydawnictwo AR, Poznań: 1-416.

Olaczek R., 1972, Formy antropogenicznej degeneracji leśnych zbiorowisk roślinnych w krajobrazie rolniczym Polski niżowej [Anthropogenic forms of degeneration of woodland communities in agricultural landscape of lowland Poland], Wydawnictwo UŁ, Łódź: 1-170.

Olaczek R., 1974, Kierunki degeneracji fitocenoz leśnych i metody ich badania [Trends of forest phytocoenoses degeneration and methods of their investigation], Phytocoenosis 3(3/4): 179-190.

Ostrowska A., Gawliński S. \& Szczubiałka Z., 1991, Metody analizy i oceny właściwości gleb i roślin [Methods of analysis and evaluation of soil properties and plants], Instytut Ochrony Środowiska, Warszawa: 1-334.

Pawłowski B., 1972, Skład i budowa zbiorowisk roślinnych oraz metody ich badania [The composition and structure of plant communities and their methods of study], [in:] W. Szafer, K. Zarzycki (eds.), Szata roślinna Polski [The vegetation of Poland], PWN, Warszawa: 237-268.

Ponge J. F., 2003, Humus forms in terrestrial ecosystems: a framework to biodiversity, Soil Biology and Biochemistry 35: 935-945.

Prusinkiewicz Z., 1994, Leksykon ekologiczno-gleboznawczy [Lexicon ecological and soil], PWN, Warszawa: 1-289.

Puchalski T., 2000, Rębnie w gospodarstwie leśnym - Poradnik leśniczego [Cutting systems in forestry - Guide forester], PWRiL, Warszawa: 1-290.

Rosenvald R. \& Lõhmus A., 2008, For what, when, and where is green-tree retention better than clear-cutting? A review of the biodiversity aspects, Forest Ecology and Management 255: 1-15.
Schwickerath M., 1954, Die Landschaft und ihre Wandlung auf geobotanischer Grundlage entwickelt und erläuter im Bereich des Messtichblattes Stolberg. Aachen: $1-128$.

Siira-Pietikäinen A., Haimi J. \& Siitonen J., 2003, Shortterm responses of soil macroarthopod community to clear felling and alternative forest regeneration methods, Forest Ecology and Management 172: 339-353.

Siira-Pietikäinen A., Pietikäinen J., Fritze H. \& Haimi J., 2001, Short-term responses of soil decomposer communities to forest management: clear felling versus alternative forest harvesting methods, Canadian Journal of Forest Research 32: 88-99.

Stephens S. S. \& Wagner M. R., 2007, Forest plantations and biodiversity: a fresh perspective, Journal of Forestry $105: 307-313$.

Thompson III F. R. \& DeGraaf R. M., 2001, Conservation approaches for woody, early successional communities in the eastern USA, Wildlife Society Bulletin 29: 483-494.

Trani M. K., Brooks R. T. Schmidt T. L., Rudis V. A. \& Gabbard C. M., 2001, Patterns and trends of early successional forests in the eastern United States, Wildlife Society Bulletin 29: 413-424.

Trzciński W., 1989, Systematyka gleb Polski [The taxonomy of Poland soils], Roczniki Gleboznawcze 40(3-4), Warszawa: 1-150.

Wright C. J. \& Coleman D. C., 2002, Responses of soil microbial biomass, nematode trophic groups, N-mineralization, and litter decomposition to disturbance events in the southern Appalachians, Soil Biology and Biochemistry 34: 13-25.

Wu L., Shinzato Y., Chen C. \& Aramoto M., 2008, Sprouting characteristics of a subtropical evergreen broadleaved forest following clear-cutting in Okinawa, Japan. New Forests 36: 239-246. DOI 10.1007/s11056008-9096-5.

Wu L., Shinzato T., Nishihata O. \& Hagihara A., 2001, Natural regeneration by seedling of evergreen broadleaved forest five years after clear cutting in Okinawa, Japan, Scientific Bulletin of the Faculty of Agriculture of the University of Ryukyus 48: 165-174.

Zerbe S., 2002, Restoration of natural broad-leaved woodland in Central Europe on sites with coniferous forest plantations, Forest Ecology and Management 167: $27-42$. 